\title{
THE MICROFINANCE INSTITUTIONAL SUSTAINABILITY AND EMPOWERMENT OF WOMEN BORROWER'S IN MALAYSIA: AN EMPIRICAL REVIEW
}

\author{
Ali Arshad ${ }^{1}$, Abul Bashar Bhuiyan², Aza Azlina Md Kassim³ , Md Jafor Ali ${ }^{4}$, Muhammad Saad \\ ${ }^{1,2,3}$ Faculty of Business and Accountancy, Universiti Selangor, Malaysia \\ ${ }^{4}$ Faculty of Business Administration, Islamic University, Bangladesh \\ ${ }^{5}$ Fast School of Management, National University of Computer and Emerging Sciences, Pakistan
}

\begin{abstract}
The fundamental aims of this study to construct a new framework between Microfinance Institution's (MFIs) financial sustainability and social, economic and household women empowerment in Malaysia. The study used both quantitative and qualitative approach. The study used available online empirical recourses by the name of Microfinance Institution's (MFIs) sustainability and sustainable and social, economic and household women empowerment in different online database sources such as Google Scholars, Springer Link, Wiley, Science Direct, JSTOR, Emerald full text, Scopus, and EBSCO HOST etc. The summary of literature review revealed that it is the unique goal of MFIs for poverty reduction mission through ensuring of financial sustainability while contribution impact in the society. It has also revealed that it is the way the social mission of poverty alleviation through serving the poorest has been overshadowed by profit motive. However, profit orientation of the microfinance industry also emphasis on profit earning. The present study will be recommended for policy considerations for the successful and effective operation of microfinance programs by providing the necessary guidelines for the proper utilization of loan for women borrowers in Malaysia.
\end{abstract}

Keywords: Microfinance, Institutional Sustainability, Empowerment, Women Borrower, Malaysia

\section{INTRODUCTION}

Poor women are ignored in most parts of the society. They are marginalized and have no opportunities for self-sufficiency, and thus, become dependent on charity or welfare. Hence, poor women lose their self-confidence because they cannot be fully self-supporting. Denied opportunities deprive poor women of the pride of accomplishment. This situation, in turn, leads to psychological, social, and mental health problems.

As a result, some started believing that access to private capital is the only path to establish sustainable and effective microfinance program (Akula, 2010; Chen et al., 2010). Conversely, it also proves as profitable industry to investment for institutional investors (Evans, 2010; Gokhale, $2009 b$ ). The industry therefore, witness a rapid transformation and commercialization that intended for profitable microfinance services (Berger, Goldmark, \& Sanabria, 2006; Briere \& Szafarz, 2015; Campion, White, \& Network, 1999; Chahine \& Tannir, 2010; Chen et al., 2010; Christen \& Drake, 2002; Drake \& Rhyne, 2002; Hishigsuren, 2006; Janda \& Zetek, 2014; Ledgerwood \& White, 
2006; Poyo \& Young, 1999; Radhakrishnan, 2015; Rhyne, 2001, 2008; Rosenberg, 2007; Siriaram \& Upadhyayula, 2004; M. Sriram \& Upadhyayula, 2002; M. S. Sriram, 2010; Tiwari \& Anjum, 2015; G. Woller, 2002).

It triggered the tension that MFIs' original mission of poverty alleviation might overshadowed by the profit orientation; generally known as mission drift that has illustrated in various studies (Abeysekera, Oguzoglu, \& Le, 2014; Abrar \& Javaid, 2014; Beatriz Armendariz, D'Espallier, Hudon, \& Szafarz, 2011; Beatriz Armendáriz \& Szafarz, 2011a; Caserta \& Reito, 2013; Christen \& Cook, 2001; Robert Cull et al., 2007; Evans, 2010; Ferdousi, 2015; Frank, Lynch, \& Schneider-Moretto, 2008; B. Gutiérrez-Nieto, Serrano-Cinca, \& Mar Molinero, 2009; N. Hermes et al., 2011; Kar, 2012, 2013a; R. Mersland \& Strøm, 2010; Nurmakhanova et al., 2015; Olivares-Polanco, 2005; Piot-Lepetit \& Nzongang, 2014; S. Quayes, 2012, 2015). Nevertheless, not all above studies found evidence of mission drift rather indicated mixed and conflicting results that makes the concern more complex and demanded more empirical studies.

However, including academics, global media and the pioneer of microcredit Muhammad Yunus express their deep concern on this movement (Bajaj, 2010; Burgis, 2008; Business, 2007; Economist, 2008, 2009; Evans, 2010; Gokhale, 2009b; Malkin, 2008; Salmon, 2011; Saltmarsh \& Contiguglia, 2009; Mohammad Yunus, 2010). Though some reports pointed institutional investors are behind the reason of mission original, despite they are also well aware about their double bottom line of investment in microfinance (Brau, Cardell, \& Woodworth, 2015; Dieckmann, Speyer, Ebling, \& Walter, 2007; Ding, Sun, \& Au, 2014; Goodman, 2006; Ledgerwood, Earne, \& Nelson, 2013; Renneboog, Ter Horst, \& Zhang, 2008; Rajdeep Sengupta \& Craig P Aubuchon, 2008; Steger, 2012; Wilburn \& Wilburn, 2014).

Empowerment is a means to achieve basic opportunities for poor women. Empowerment includes encouraging and developing the skills for self-sufficiency, with a focus on eliminating the future need for charity or welfare. In spite of remarkable economic growth, reducing the interethnic income disparity and the economic imbalance, especially hard-core poverty and women empowerment, is the prime threat to declare Malaysia as a completely developed country by 2020. Existing literature reveals limited studies on the assessment of AIM microcredit performance concerning the success stories of women empowerment in Malaysia. Thus, this study will analyze the contribution of AIM to the household income and the empowerment of poor women borrowers in Malaysia. This research will propose the future direction for the effective use of credit for IGAs and the development of poor women in Malaysia.

\section{Background of the study}

The revolution in microfinance industry was observed after the year 1974 when Muhammad Younus established Grameen Bank in Bangladesh. During the early days of 2011, microfinance achieved a milestone of reaching more than 200 million poor across the globe (Maes \& Reed, 2012). According to the data reported to MIX market in 2014, the total gross loan portfolio of MFIs has reached 78 billion USD. Therefore, microfinance was considered as a best available tool for sustainable development and growth. This was also endorsed as Muhammad Younus received Nobel Prize in 2007 for their contribution to reducing poverty through microfinance.

There are two major goals for microfinance institutions (Chenuos et al., 2014). The first goal of MFI is to contribute to development by approaching a maximum number of clients and reaching the poorest (Nanayakkara, 2012). The second important goal for MFIs is to reach poor clients by achieving financial sustainability. According to Olasupo et al. (2014), MFIs management should be efficient in promoting both the objectives. G. M. Woller et al. (1999) also introduced 
two approaches known as "the Institutionist approach” and "the Welfarist Approach.” Institutionist approach sticks with financial sustainability of institutions and poverty alleviation simultaneously whereas, Welfarists approach emphasized on reaching poor clients by using subsidized funds.

Since microfinance, promises to develop its customers and provide capital to overcome poverty. Therefore, understanding of MFIs sustainability is essential for the well-being of individuals and business (Muwamba, 2012). The sustainability achievement, in this case, means attaining the financial sustainability along with the attainment of reduction in poverty level (Nanayakkara, 2012). The term sustainability was commonly used in many fields such as environmental science, development economics, and agricultural sector development, particularly in the developing world where agriculture is the major economic sector or covers the significant share of the gross domestic production of the countries. Sustainability is commonly known as the organization's ability to cover both its operational and financing cost from its revenues and also expanding its services (M. W. Rahman \& Luo, 2012). Chaves and GonzalezVega (1996) views sustainability as the organization's ability to use its financial resources or borrowings on market rates for providing financial services on regular basis. Okumu (2007) cited the definition of sustainability as the institution's ability to generate enough reserves for capitalization by covering its operational cost.

\section{PERFORMANCE OF MICROFINANCE INSTITUTIONS}

Sustainability normally taken as recovery of the full cost of MFI or generating sufficient profit to continue the operations of MFIs without depending on external supports by donors and government subsidies (CGAP, 2004). It is commonly used as financial aspects by researchers regarding financial sustainability only. Financial sustainability was one of the key measurement variables for sustainability of microfinance institutions (Ayayi \& Sene, 2010; Basharat, Hudon, \& Nawaz, 2015; M. W. Rahman \& Luo, 2012; Sekabira, 2013; Tehulu, 2013). Several studies have mentioned that for an MFI to be sustainable, it should be financially self-sufficient (Gibbons \& Meehan, 1999; Kar, 2013b; Kinde, 2012; Morduch, 1999a).

However, Bhanot, Bapat, and Connelly (2015) mentioned that in reaching sustainability, financial sustainability is just one dimension. Under 'Welfarist Approach', for an institution to be sustainable, the core function of MFIs were to reach the maximum poor clients (Hulme \& Mosley, 1996; Kipesha \& Zhang, 2013; Morduch, 2000; G. M. Woller et al., 1999). Mahajan and Ramola (1996) measures the sustainability of MFIs by using financial sustainability and outreach. They were concerned that increase in focus on financial sustainability may result in the shift in outreach. Millson (2013) also measures sustainability regarding both financial sustainability and outreach to the poor.

Morduch (2000) clearly discuss the winning proposition for sustainability of MFIs if both costs of operation and maximum outreach to the poor people achieved without external support by donor's funds or government subsidies. Shahidur R Khandker and Khalily (1996) discuss the sustainability of Bangladesh Rural Advancement Committee's regarding financial viability, institutional sustainability and sustainability of targeted beneficiaries. In their study, financial viability approximates program ability to recover its cost of operation from its revenues. Institutional sustainability approximate MFIs ability to continue its activities on a sustained basis and beneficiaries' sustainability implies the positive impact of microfinance services on the growth of recipients and their ability to repay their loan within given time frame (Shahidur R Khandker \& Khalily, 1996). 
The triangle of microfinance introduced by Zeller and Meyer (2002) also support the above studies. According to Zeller, successful microfinance institutions should be financially sustainable, have positive outreach to the poor and should be helpful in poverty alleviation. Yaron (1992) also considers financial sustainability and outreach as a benchmark for sustainable MFIs if subsidy dependence is zero. Thus, sustainability of MFIs can be measured using financial sustainability and outreach (Annim, 2012; S. Quayes, 2012; Zeller \& Meyer, 2002). Rauf and Mahmood (2009) uses six dimensions of outreach to approximate MFIs performance. They used OSS and FSS to determine cost and length of outreach. Under institutionalist view, Kipesha and Zhang (2013) found that outreach has a positive correlation with both profitability and sustainability measures. Simultaneously, using Welfarists approach, results does not show the tradeoff between outreach and sustainability.

Outreach and financial sustainability have an active relationship with MFIs sustainability (Louis, Seret, \& Baesens, 2013). Also, MFIs can achieve sustainability if they increase outreach to target poor and achieve financial sustainability simultaneously (De Crombrugghe, Tenikue, \& Sureda, 2008). MFIs, to remain sustainable, should use appropriate processes and structures to facilitate its customers and continue its operations without any interruption (Rao, 2014).

\section{Sustainable Microfinance Institutions}

There are large number of microfinance programs are still depending on donor subsidies to meet the high costs, which means they are not institutional sustainable (Niels Hermes \& Lensink, 2011). In the 1990s, the issue of financial sustainability of microfinance institutions gave rise to an important debate between the financial systems approach and the poverty lending approach (Robinson, 2001). The financial systems approach emphasizes the importance of financially sustainable microfinance programs (Robinson, 2001). This approach stresses the importance of being able to cover the cost of lending money out of the income generated from the outstanding loan portfolio and to reduce operational costs as much as possible (Robinson, 2001).

On the other hand, the poverty lending approach, however, concentrates on using credit to help overcome poverty, primarily by providing credit with subsidized interest rates (Robinson, 2001). The advocates of this approach argue that the poor cannot afford higher interest rates (Robinson, 2001). Therefore, aiming at institutional sustainability ultimately goes against the goal of serving large groups of poor borrowers (Niels Hermes \& Lensink, 2011). In other words, there is a trade-off between sustainability and outreach (Beatriz Armendáriz \& Szafarz, 2011b; Robert Cull, Demirgüç-Kunt, \& Morduch, 2011; Robert Cull \& Morduch, 2007; Niels Hermes \& Lensink, 2011; N. Hermes et al., 2011). The proponents of the financial services approach, however, claim that empirical evidence neither shows that the poor cannot afford higher interest rates, nor that there is a negative correlation between the financial sustainability of the institution and the poverty level of the clients (N. Hermes et al., 2011). During recent years, the debate appears to have been settled in favor of the proponents of the financial systems approach (Niels Hermes \& Lensink, 2011). In fact, the importance of striving for institutional sustainability has been embraced by most parties involved in the microfinance discussion (Niels Hermes \& Lensink, 2011).

In parallel with this development, donors, policy makers, and other financers of microfinance have recently made a shift from subsidizing MFIs institutions toward a focus on financial sustainability and efficiency of these institutions (Niels Hermes \& Lensink, 2011). Among other things, this increased focus on financial sustainability and efficiency is due to a number of developments the microfinance business has been recently confronted with, such as the increasing competition among MFIs, the commercialization of microfinance, technological change 
that also has become available for, and implemented in microfinance, and financial liberalization and regulation policies of the government (Rhyne \& Otero, 2006).

At the same time, however, there remains a huge variety in MFIs in terms of their financial sustainability. According to rough estimations, only 1-2\% of all MFIs in the world (i.e., some 150 organizations) are financially sustainable (Niels Hermes \& Lensink, 2011). In most cases, these are larger, mature, regulated, and relatively well-known MFIs. Some $8 \%$ of all MFIs are close to being profitable (Niels Hermes \& Lensink, 2011). Both these groups of MFIs are considered to be commercial organizations, focusing on profitability or sustainability (Niels Hermes \& Lensink, 2011). A third group of organizations (20\% of all MFIs) consist of mostly NGOs, which are not yet financially sustainable, but may become sustainable in the near future (Niels Hermes \& Lensink, 2011). The remaining group of MFIs (70\% of all organizations) consist of smaller, startup organizations, which are still far from being financially sustainable and are, therefore, heavily dependent on subsidies (Niels Hermes \& Lensink, 2011).

According to Ledgerwood, J. in 1999 institutional sustainability or financial performance of microfinance institution consists of profitability, portfolio quality, productivity, and financial viability (Ledgerwood, 1999). Whereas, financial viability consists of operational selfsufficiency (OSS) \& financial self-sufficiency (FSS), which indicates an indicator of MFI's ability to cover its costs with earned revenues (Ledgerwood, 1999). Moreover, Armendariz de Aghion, B. and J. Morduch in 2005 used operational self-sufficiency (OSS) \& financial selfsufficiency (FSS) on their study for MFI's performances evaluations (Armendariz de Aghion \& Morduch, 2005).

\section{Empirical Review of Financial Sustainability}

The measurement of sustainability has become a crucial topic. MFIs sustainability was discussed in very few empirical studies in different countries. In these studies, sustainability of microfinance institutions was measured using different ratios. However, no definite measure is available for determining sustainability level of microfinance institutions (Mia et al., 2015; Rai \& Rai, 2012). Tehulu (2013) in his study used FSS to measure MFIs financial sustainability in East Africa. Another study by Kar (2013) has also used financial self-sufficiency ratio as an approximation for financial sustainability of MFIs. The financial self-sufficiency ratio has become a popular measure of MFI performance, and it has been adopted by the Micro Banking Bulletin (MBB) as its principal measure of financial sustainability (Manos \& Yaron, 2009). Based on FSS data published in the MBB of spring 2008, it appears that out of 340 MFIs reviewed in 2006, 244 (72\%) were financially self-sufficient.

Kazemian et al. (2014) have also used financial self-sufficiency as an estimate for sustainability of Amanah Ikhtiar Malaysia. The study was focused on the relationship between market orientation and MFI sustainability. Financial sustainability for MFIs in Ethiopia was also determined using financial self-sufficiency ratio (Kinde, 2012). M. A. Rahman and Mazlan (2014a) investigated the drivers of MFIs financial sustainability in Bangladesh. Study approximated financial sustainability by using financial self-sufficiency ratios. Another study to measure the sustainability of MFIs by using FSS ratio have been done by Nwachukwu (2014).

Ayayi and Sene (2010) used OSS to estimate the sustainability of 217 MFIs for the year ranging 1998-2006. Lenssen et al. (2014) and Kaur (2014) has also used OSS to measure the sustainability of MFIs in India post-Andhra Pradesh crisis.. Ngo et al. (2014) also investigated the relationship between the scale of operation and MFIs sustainability in Bangladesh. In their study OSS ratio was used to measure sustainability. Islam et al. (2014) also used OSS to measure the MFIs financial sustainability. They investigated the impact of interest rate cap effect and cost 

structure on the financial sustainability of MFIs in Bangladesh. V. L. Bogan (2012), V. L. Bogan (2008) and V. Bogan et al. (2007) have emphasized that to be financially sustainable MFIs needed to be operationally self-sufficient.

Mia et al. (2015) measured the sustainability of MFIs by using financial revenue over the asset. The result showed that MFIs failing to achieve financial sustainability were related to higher leverage. Daher and Le Saout (2015) and Chenuos et al. (2014) have measured sustainability of MFIs by using return on asset. Khandker and Khalily (1996) discuss sustainability of Bangladesh Rural Advancement Committee's (BRAC) regarding financial viability, institutional viability and sustainability of targeted beneficiaries.

Several indices were also found to determine the sustainability of Microfinance institution. Subsidy dependence index (SDI) analyzes the sustainability of four rural financial institutions (RFIs) (Yaron, 1992). These institutions include Badan Kredit Kecamatan Indonesia, Grameen Bank Bangladesh, Bank for Agriculture and Agricultural Cooperatives Thailand and Bank Rakyat Indonesia Unit Desa. SDI was designed to evaluate the progress of RFI for getting free from dependence on subsidies. It also evaluates the level of dependency on grants when RFIs are compared with a similar institution. It also investigates the degree of interest RFI should adopt to be independent of subsidies. Negative SDI indicates not only that RFIs have attained FSS but also profits exceeding the number of subsidies and also RFI have the capacity to reduce their lending interest rate. Zero SDI means RFIs have achieved FSS. Contrary, if SDI is 100 percent, the lending rate should be doubled to reach FSS.

However, according to Nanayakkara (2012), the reliance on SDI is not acceptable as it indicates the dependence level of subsidies only and does not consider the outreach. Furthermore, when MFI tends to achieve subsidy independence by using SDI, it may deviate from its mission of poverty alleviation by charging a high-interest rate to poor customers.

Another index incorporated by Christen (1995) is commonly known as financial selfsufficiency index. Three types of adjustments are made to revenues and costs when the FSS is computed: adjustments for inflation, adjustments for subsidies, and adjustments for loan loss provisions and write-offs. The adjustment for inflation counters the decrease in value of financial assets. Furthermore, the adjustment of subsidy accounts for three types of grants: concessionary borrowings, cash donations, and in-kind grants. The adjustment for loan loss provisions and writeoffs accounts for variation in the recognition of delinquencies and writing off of bad loans. Christen (1995) make the points that the SDI and the FSS are compatible, and that the FSS adjusts the financial statements in line with market rates as if the MFIs were not subsidized.

A financial sustainability index was developed by Rai and Rai (2012) to evaluate the sustainability level of MFIs in India and Bangladesh in the year 2009-2010. Sustainability score of MFIs was determined using four financial indicators. These include PAR>30, OER, leverage and OSS. The base score for MFIs sustainability in the year 2010 was 63.25. The study also determines the factors which influence the sustainability of MFIs. Rai and Rai (2012) have measured sustainability by using an operational self-sufficiency ratio. Above studies depict that financial sustainability, a physical parameter, can be monitored and measured using several indicators, including return on asset, financial revenue to total asset, FSS and OSS ratios. However, CGAP, MIX market and Micro Banking Bulletin (MBB) have emphasized FSS and OSS as their principle instruments for calculating financial sustainability (CGAP, 2003; Manos \& Yaron, 2009). Several studies also stress that financial sustainability is measured as financial self-sufficiency and operational self-sufficiency (V. Bogan et al., 2007; Chaves \& GonzalezVega, 1996; R. Cull \& Morduch, 2007; Islam et al., 2014; Lenssen et al., 2014; M. A. Rahman \& Mazlan, 2014a; Rai \& 
Rai, 2012). Financial self-sufficiency implies MFIs ability to cover the cost of operations without dependency on subsidies, and operational self-sufficiency implies MFIs ability to cover the cost of its revenue (CGAP, 2003).

Sustainability has been commonly used in financial aspects by researchers regarding financial sustainability only. However, Bhanot et al. (2015) mentioned that in reaching sustainability, financial sustainability is just one dimension. Mahajan and Ramola (1996) measures the sustainability of MFIs by using financial sustainability and outreach separately. He showed his concern that increase in focus on financial sustainability results in the shift in outreach. Millson (2013) also measures sustainability regarding both outreach and financial sustainability. Thus, sustainability of MFIs can be measured using financial sustainability and outreach (Annim, 2012; Quayes, 2012; Zeller \& Meyer, 2002). Mutually, FSS and Outreach are necessary for MFI performance without displacement of one for the other (Kar, 2013; Kinde, 2012). In a study by Annim (2012), analysis of the data show that MFIs that have better depth of outreach were operationally self-sufficient. Their study investigated the impact of FSS and OSS on outreach. Another study was done to determine the trade-off among outreach and financial sustainability by using operational self-sufficiency as a measure of financial sustainability (zero \& Rani, 2012). Results suggest that outreach and financial sustainability were interdependent.

Zeller and Meyer (2002) introduced "the triangle of microfinance" which was consistent with the above studies. According to Zeller, successful microfinance institutions should be financially sustainable, have positive outreach to the poor and should be helpful in poverty alleviation. Yaron (1992) also considers financial sustainability and outreach as a benchmark for sustainable MFIs if subsidy dependence is zero. Under Welfarists approach, Kipesha and Zhang (2013) results do not show the tradeoff. Other researchers also found that sustainable MFIs achieve financial sustainability along with poverty outreach simultaneously (Adhikary \& Papachristou, 2014; De Crombrugghe et al., 2008). Murdoch (2000) and Paxton (2002) clearly discuss the winning proposition for sustainability of MFIs if both costs of operation and maximum outreach to the poor people were achieved without external support of donor funds or government subsidies. Similarly, Rai and Rai (2012) also found that breadth of outreach influence OSS of MFI.

A study by Bhanot et al. (2015) supports the above argument who has also developed a sustainability index for MFIs in India. Their sustainability index does not include only financial indicators, but also include outreach measures. OSS, BO, and DO were used to determine the sustainability scores for MFIs in India. MFIs sustainability score ranges varies from 0.80 (the maximum) to 0.26 (the minimum). However, the index does not include the important financial indicator of FSS which is critical as it determines MFIs to continue its operations without depending on subsidies (CGAP, 2003; Morduch, 2000). Thus, measurement of sustainability level has been a serious problem that is not discussed. Without understanding the sustainability level of microfinance institutions, it would not be significant to investigate the drivers which influence MFIs sustainability. In the next section, we will discuss the various factors that are deemed important for MFIs sustainability by previous researchers.

Sustainability normally taken as recovery of the full cost of MFI or generating sufficient profit to continue the operations of MFIs without depending on external supports by donors and government subsidies (CGAP, 2004). It is commonly used as financial aspects by researchers regarding financial sustainability only. Financial sustainability was one of the key measurement variables for sustainability of microfinance institutions (Ayayi \& Sene, 2010; Basharat et al., 2015; M. W. Rahman \& Luo, 2012; Sekabira, 2013; Tehulu, 2013). Several studies have mentioned that 
for an MFI to be sustainable, it should be financially self-sufficient (Gibbons \& Meehan, 1999; Kar, 2013; Kinde, 2012; Morduch, 1999).

However, Bhanot et al. (2015) mentioned that in reaching sustainability, financial sustainability is just one dimension. Under 'Welfarist Approach', for an institution to be sustainable, the core function of MFIs was to reach the maximum poor clients (Hulme \& Mosley, 1996; Kipesha \& Zhang, 2013; Morduch, 2000; Woller et al., 1999). Mahajan and Ramola (1996) measures the sustainability of MFIs by using financial sustainability and outreach. They were concerned that increase in focus on financial sustainability may result in the shift in outreach. Millson (2013) also measures sustainability regarding both financial sustainability and outreach to the poor. Murdoch (2000) clearly discusses the winning proposition for sustainability of MFIs if both costs of operation and maximum outreach to the poor people achieved without external support by donor's funds or government subsidies. Khandker and Khalily (1996) discuss the sustainability of Bangladesh Rural Advancement

Committee's regarding financial viability, institutional sustainability and sustainability of targeted beneficiaries. In their study, financial viability approximates program's ability to recover its cost of operation from its revenues. Institutional sustainability approximate MFIs ability to continue its activities on a sustained basis and beneficiaries' sustainability implies the positive impact of microfinance services on the growth of recipients and their ability to repay their loan within given time frame (Khandker \& Khalily, 1996).

The triangle of microfinance introduced by Zeller and Meyer (2002) also supports the above studies. According to Zeller, successful microfinance institutions should be financially sustainable, have positive outreach to the poor and should be helpful in poverty alleviation. Yaron (1992) also considers financial sustainability and outreach as a benchmark for sustainable MFIs if subsidy dependence is zero. Thus, sustainability of MFIs can be measured using financial sustainability and outreach (Annim, 2012; Quayes, 2012; Zeller \& Meyer, 2002). Ruff and Mahmood (2009) use six dimensions of outreach to approximate MFIs performance. They used OSS and FSS to determine cost and length of outreach. Under institutionalist view, Kipesha and Zhang (2013) found that outreach has a positive correlation with both profitability and sustainability measures. Simultaneously, using Welfarists approach, results do not show the tradeoff between outreach and sustainability.

Outreach and financial sustainability have an active relationship with MFIs sustainability (Louis et al., 2013). Also, MFIs can achieve sustainability if they increase outreach to target poor and achieve financial sustainability simultaneously (De Crombrugghe et al., 2008). MFIs, to remain sustainable, should use appropriate processes and structures to facilitate its customers and continue its operations without any interruption (Rao, 2014). In the next section, we discuss financial sustainability and outreach to understand the sustainability of MFIs. Microfinance, the most successful and powerful weapon in the war of poverty alleviation (Yunus \& Abed, 2004). The journey of microfinance program started as an alternative type of credit institution for rural populations who has no other option. Small credit loan has been given to very poor group of people and involve them in micro-business which generate income. Tho the uniqness of microfinance ideology is its dual objectives nature; (i) profit making and (ii) social (Hartarska \& Nadolnyak, 2007). Therefore an efficient microfinance institutions have to cover all administrative expenses, loan losses, financing capital and surplus for further expenses from operating income (profit making objective) and operational efficiency to reach the poorest (social objective) (Thapa, 2007). Consequently microfinance institutions attract its client through innovative approaches such as 
progressive lending, group lending, collateral substitutes and regular repayment schedules (Thapa, 2007).

During 1990s the issue of financial viability focused for the first time by academic scholar and policy makers (Robinson, 2001; Tucker, 2001). Since that number of research has been conducted, policies and strategies have been changed; issues have been taken under consideration of implementation. Moreover till to date various research agreed on the extreme importance of financial viability of microfinance institutions for its long term operations in the market (CGAP, 2003; Robert Cull, Demirgüç-Kunt, \& Morduch, 2009; Begoña Gutiérrez-Nieto, Serrano-Cinca, \& Mar Molinero, 2007; N. Hermes et al., 2011; MIX, 2005, 2008, 2009). Number of issues has been identified for the increasing interest on efficiency and financial viability, alike the commercialization or transformation of MFIs, competition among existing MFIs, economic liberalization, government regulating policies and most importantly technological revolution in recent era (Rhyne \& Otero, 2006).

More than US \$ 1 billion per year has received by MFIs in donation from both govt. and private sector in last 20 years (CGAP, 2005). However about 5\% of global MFIs found working efficiently without external subsidies conversely rest of them extremely depend on it to operate effectively (UNCDF, 2005). These subsidies also provided in various form (i) direct (i.e. cash, donations) (ii) indirect (i.e. asset, soft-skill, training, technology). Armendariz \& Morduch argued that beyond mentioned form there few more forms (i.e. tax holidays, loan guarantees, soft equity, or public goods) of subsidies also have practiced but this information might not place open to the data collector (B. Armendariz \& Morduch, 2005). However in a previous study Morduch identified this huge adjustment difference where he calculated the total direct and indirect subsidies of Grameen Bank for 1985-1996 was US\$ 144 million while it was reported only US\$ 1.5 million (Morduch, 1999b).

Such comprehensive donor dependency of MFIs has raised several arguments on sustainability and efficiency of MFIs. Hollis \& Sweetman addressed that financial sustainability of MFIs is very important matter that should be examined keep MFIs sustainable (Hollis \& Sweetman, 1998). Financial sustainability which is one of the objective of MFI defined as the ability to cover all operational cost with its generated revenue and also able to finance future growth from that (Ayayi \& Sene, 2010). Lack of these capabilities are some reasons why MFIs that are strongly dependent on external subsidies generally less sustainable and efficient (Rhyne, 1998). Various study found number of active borrowers enhance the deposit scheme and internal cash flow, which brings financial sustainability in MFIs. Therefore, MFIs should practice offering trasparent and competitive interest rates to allow their borrowers to enhance financial sustainability continuously (Acclassato, 2008).

Sevaral previous studies explained that there are a significant relation between financial self-sufficiency and operating efficiency. Although the prime tensions are subsidies undercut both efficiency and scale within the microfinance institution, and pervert the market by supporting more inefficient institutions (M. Hudon \& Traca, 2011). In a different study found that smart subsidies enhance microfinance institution's efficiency and help to develop better infrastructure (B. Armendariz \& Morduch, 2005). However it is surprising that only limited studies have identified evidence of subsidies impact on the microfinance performance (M Hudon, 2006) and (R. J. Cull, Demirgüç-Kunt, \& Morduch, 2006). Microfinance institutions are a special form of financial service provider, but it doesn't mean that operational efficiency and sustainability are not important for them like traditional bank. However, assessment and measurement mechanism may vary from microfinance institutions compare to traditional financial institutions. Production oriented non- 
government MFIs have been revealed as the most efficienct from previous studies (Begoña Gutiérrez-Nieto et al., 2007).

Acclassato in 2008 revealed that interest rate ceilings do not protect small businesses. In actual practice, interest rate ceilings damage microfinance institutions (Acclassato, 2008). The findings also mentioned that microfinance institutions need to price loans in a realistic way to be sustainable and to reach a large number of clients. The study has recommended the promotion of transparency on interest rates to stimulate competition among MFIs as a way of protecting borrowers. Moreover, the financial sustainability of MFIs is based on the capability to meet all costs on an adjusted basis and alludes to the use of the institution's own available sources in operating without on-going subsidies from donors or losses (Guntz, 2011).

Furthermore, a different examination by Agbodjan on the results of the prudential regulations showed that the non-observance of some "prudential ratios" by MFIs did not adversely affect their financial and organizational performance. Moreover, in view of the very strong correlation between the sustainability and the profitability of these institutions, the recommended strategy should consist of the removal of the framing of lending rates to make these neighbourhood credit institutions more profitable (Agbodjan, 2002). In addition, the cost efficiency of MFIs is affected by average loan size, proportion of net assets, financial sufficiency, financial leverage, business experience, and proportion of farm loans (Gregoire \& Ramírez Tuya, 2006). In 2012, Kinde showed that the financial sustainability of Ethiopian MFIs has been affected by the breadth and depth of outreach, dependency ratio, and cost per borrower. He has also concluded that during the study periods, the microfinance capital structure and staff productivity have insignificant effects on the financial sustainability of MFIs in Ethiopia (Kinde, 2012). Thapa (2007) showed that MFIs is considered as financially self-contained if their operating incomes are able to sustain all loan losses, administrative costs, and financing costs after synthesizing inflation rates and subsidies from donors and treating all funding as if it had a commercial cost.

The FSS of MFIs depends on the performance of the return on assets (ROA) and return on equity (ROE) (Tucker \& Miles, 2004). The authors concluded that providing financial service to the poor is an expensive proposition, which can be a deterrent for numerous MFIs to reach selfsufficiency, and may require them to acquire continued subsidies. The cost argument has an important flaw: client retention, which is a critical aspect of financial sustainability and a key measure of social influence, is significantly higher in rural markets (Epstein \& Yuthas, 2013). The study suggested that by operating in rural markets, MFIs may be able to increase both social influence and financial performance. However, in a different study, the authors asserted that MFIs can significantly improve their financial sustainability and social influence by increasing the focus on trust (Epstein \& Yuthas, 2011).

Without maximizing the loan size and increasing the cost of monitoring, the difficulties to meet expenses on partial unsecured and small loan can be covered. Therefore to develop better financial situation MFIs should improve the policy to standardize interest rate threshold or maximize the number of borrower per loan office based on collective delivery method (De Crombrugghe et al., 2008). MFIs operate primarily in nations with a relatively minimum degree of overall economic independence and where government intervention in the economy can reduce their sustainability (Crabb, 2008). His observation has resolved the issue with regard to how remarkable is the economic environment in host countries where MFIs operate as a factor in their ability to reach their goal.

$\mathrm{Al}$ Atoom and Abu Zerr conducted three phases of analysis: taking four financial factors of financial sustainability, introducing the countries' macroeconomic regime factors, and 
integrating both micro- and macro-factors together. Results showed that Jordanian MFIs have more financial sustainability than those of other Arab and Asian countries (Al Atoom \& Abu Zerr, 2012). Moreover, these MFIs have less significant effect on the financial sustainability of the world's MFIs. Their study recommended that the government should improve the macroeconomic regime policies, financial policies, and monetary policies to help MFIs achieve sustainability. This recommendation finds support in the observation that the country-level context is an important determinant of performance of microfinance institutions and a continues defects for the environment where it has pointed (Ahlin, Lin, \& Maio, 2011).

Profit margin, operational self-sufficiency (OSS), ROA, and gross loan portfolio-to-total asset ratio considerably affect the other components by establishing the financial sustainability dimension (Anduanbessa, 2009). Borrowers' outreach is growing as evidenced by the opening of branches in almost all regions of Tanzania; nevertheless, landing activities are still brought to around city areas (Chijoriga, 2000). His study concluded that operational performance demonstrates less loan repayment rates. Conversely, capital structure reveals a high dependence on donor or government subsidy. Moreover financial sustainability increases through well mechanisms practice of external governance in microfinance institutions (B. S. Bassem, 2009). The study also proposed that other factors, such as regulation and the use of the individual lending methodology, can lead to sustainability.

Interest rates, administrative efficiency, loan officer productivity, and staff salaries are significant determinants of FSS, but staff productivity measures and institutional scale are unrelated to FSS (G. Woller \& Schreiner, 2002). The study found a statistically significant and positive relationship between FSS and depth of outreach. However, earning profits is possible while serving the poor, but a trade-off emerges between profitability and serving the poorest (Robert Cull \& Morduch, 2007). They concluded that raising fees to extremely high levels does not ensure higher profitability, and the benefits of cost-cutting diminish when serving better-off customers. Consultative Group to Assist the Poor came up with the guideline for microfinance institutions on the financial terms' definitions, ratios and adjustments in 2003 and other rating agencies, multinational banks, donors, NGOs, private voluntary organizations etc. agreed on that guideline. The guidelines generally divided in four categories of financial ratios: (i) profitability/sustainability, (ii) liability/asset management, (iii) portfolio quality, and (iv) productivity/efficiency.

\section{The Social Performance and Women empowerment of Microfinance Institutions}

The depth of outreach may be defined as the "poverty level of clients served by MFI" (Rao, 2014; Rauf \& Mahmood, 2009). The DO narrates the line of poverty, or the extent poor does not have access to regulated financial institutions. The proxy for DO is the average size of loan because other indicators of DO are usually expensive to collect. In recently published studies, DO was measured by average loan balance/size per borrower (Bhanot et al., 2015; Nanayakkara, 2012; Okumu, 2007). According to Mersland and Strøm (2010), for an MFI, the risk associated with variation in the average size of the loan is unpredictable. Results describe that when loan size is small, MFI will be more cost effective. As average loan size increases, it increases the average operational cost thus increasing the average profit of an MFI. However, Kumar Kar (2011) found that MFI should be careful in increasing the size of the loan as the risk associated with the loan also increases. Thus, the optimal size of the loan should be decided carefully. The increase in loan size also enhances the possibility of loan default also increases and affects MFI profitability. MFIs with smaller ALPB usually reach a large number of poor clients which shows a better depth of 
outreach. Similarly, MFIs whose ALPB is large tend to reach less poor clients, thus resulting in a mission drift (Kar, 2013).

Gashayie (2014) found that ALPB and NAB have no significant relationship with financial sustainability of MFIs (Kar \& Swain, 2014). However, several studies found that ALPB has a negative correlation with MFI financial sustainability (Hermes et al., 2011; Louis \& Baesens, 2013; Zerai \& Rani, 2012). However, Paxton (2002) using Subsidy Dependence Index (SDI) found that NAB and ALPB have a significant positive relation to MFIs financial sustainability. Quays (2012) also found that depth of outreach (DO) have a significant positive relationship with MFI financial sustainability. Several other studies also found that both ALPB and MFIs financial sustainability were positively related (Daher \& Le Saout, 2015; Kar, 2013; Kinde, 2012; Nwachukwu, 2014). The breadth of outreach refers to "the scale of operations of an MFI" (Rao, 2014). Several studies have used number of active borrowers as a measure of the breadth of outreach (Kinde, 2012; Rai \& Rai, 2012; Rauf \& Mahmood, 2009). Results of Louis and Baesens (2013) show that OSS, FSS, and BO are positively related, whereas the DO has a weaker impact on MFI profitability. Similarly, Rai and Rai (2012) also found that breadth influence OSS of MFI.

Some inconsistent results from different studies were found in the measurement for the breadth of outreach. Limited studies measure BO is using a number of women borrowers (D'espallier et al., 2011; Janda \& Turbat, 2013). According to D'espallier et al. (2011) and Janda and Turbat (2013) when MFI focus on female borrowers their performance regarding repayment increases. Furthermore, those MFIs in which female borrowers are more than male were less exposed to loan write-offs and their loan default ratio is low. However, Ayayi and Sene (2010) evaluated that female borrowers have no significant effect on the sustainability of MFIs. The literature shows that sustainability of MFI is based on four measurement variables, including FSS, OSS, depth of outreach and breadth of outreach. Researchers are facing problems in determining the consistent measurement for sustainability. In the next section, we discuss the issues in the measurement of sustainability of MFIs. Micofinance is the alternative approach of collateral free loan service provider to the poorest populations in rural area. Traditional bank has ignored these populations because the lack of collateral and the weak legitimate practice will be unable to secure loan repayment if the client reneges on loan. The borrowing options therefore was shut down for the poor from traditional credit service provider and the circumstances lead to the contineus poverty and economic inequality. Collateral free micro-credit loan service therefore received enthusiastic acceptance (Beck, Demirgüç-Kunt, \& Levine, 2007). Moreover the innovative approach of micro-lending to the social bottom line (reach out to the poor) and client's involvement in profit genareting micro-enterprise ensure comparetively very high loan repayment (B. Armendariz \& Morduch, 2005).

Nevertheless the high repayment of loans yet unable to make sure the profitability for microfinance institutions. Therefore microfinance institutions still extensively depend on various local and international donors. As a result, the great debate on microfinance profitablity and sustainability yet to be solve (Morduch, 1999b). In a different perspective there is a call for more commercialization of microfinance program to access the available large asset and finance their further operational expenses, thus greater number of poor populations will be served (Ghosh \& Van Tassel, 2008; Morduch, 2000). Once microfinance institutions able to reach their profitability from their own operations they can start borrowing from the commercial sector and reduce donor dependency. Pursuing the profitability will increase the poorest populations in a loan which is the prime concern of microfinance program. 
However the controversy arises here too on whom to serve (target group), and the level of poor people to serve (poverty level). Navajas et al. argued that microfinance institutions lending credit to the households those are nearly to the poverty line, however most of them are the richest among the poor (Navajas, Schreiner, Meyer, Gonzalez-Vega, \& Rodriguez-Meza, 2000). There are some families whose income about to poerty line, on the other hand some living under lower subsistence frontier. Few of them employed, few might involved in setting up micro-venture and others are unemployed. The very poor can realize the benefit of microfinance from its consumption smoothness (Morduch, 1998; Zeller \& Johannsen, 2006). Sevaral studies also confirmed that competition in microfinance indudtry also effets outreach of microfinance institutions in different region (Hartarska \& Nadolnyak, 2007; Olivares-Polanco, 2005).

Professor Yunus invested his idea of micro-lending to the poor who are unserve by commercial bank because of their poverty in 1970s in Bangladesh. The poor commonly considered as proper client for microfinance because they can involve in profit making venture and repay their interest for loan have taken (Morduch, 2000). Poverty and vulnerability create entrepreneurial spirit in the mind of poor people and influence them to change their destiny (Junyon Im \& Sun, 2014). But they need law enforcement to protect private properties; thus poor borrower will have incentives to genaret wealth and enrich prosperity (Ding et al., 2014; Peng, Sun, Pinkham, \& Chen, 2009). From the sustainability perspective, profitablity of microfinance institutions could be very close issue to the outreach of social bottom line as it will keep sustain the institutions to serve more client (Muhammad Yunus, 2007). Conversly profit seeking for microfinance institutions also has negative impact on outreach as it increase operational cost to serve poorer populations (R. Cull, Demirgüç-kunt, \& Morduch, 2007; R. Mersland \& Strøm, 2010). However a recent study propose a comprehensive model that include financial sustainability and outreach as endogenous variables and the results disclose that financial sustainability does not badly affect to the depth or breath of outreach (Nurmakhanova et al., 2015).

Another examination has taken place by Julia Meyer (2015) where she analyze the interaction between social and financial returns in microfinance. A multivariate regression models has ran using 1,508 observations on microfinance institutions for the period of 2004 to 2010. The result found strong evidence that microfinance institutions can achieve higher portfolio yields from more social outreach (Meyer, 2015b). Shakil Quayes (2015) has conducted a panel investigation on possible trade-off between outreach and performance using 764 microfinance institutions from 87 countries. The empirical results of this study revealed that financial performance of MFIs can be boosted by the reach out to the poor (S. Quayes, 2015). However both recent studies confirm microfinanc institutions can achieve better financial performance from their social outreach, however some market oriented strategies need to be applied.

A study on Savings and Credit Cooperative Societies (SACCOs) of Tanzania revealed that both product development and market development have significant contribution on outreach performance (Jeje, 2014). However sometime this relationship of outreach and financial perfomance can be represent negative from the country contex. Indeed a study has been taken place with an assumption that financial performance and outreach in Ethionpian microfinance institions is not related. The hypothesis has tested with three outreach and two financial sustainabilty indicators based on 5 microfinance institutions. The study concluded with negative trade-off between financial performance and outreach in Ethionpian microfinance institions (Gashayie, 2014).

Schreiner proposed an outreach framework in 2002 where author mentioned there are six aspects of social benefits of microfinance program for its poor clients, such as (i) cost of outreach 
to clients, (ii) worth of outreach to clients, (iii) depth of outreach, (iv) breath of outreach, (v) length of outreach and (vi) scope of outreach (Schreiner, 2002). The costs of outreach to clients define the transaction costs and price costs charged to the clients of microfinance program. However the worth of outreach to clients entails the willingness of microfinance clients to pay. On the other hand, the depth of outreach represents the added value of active microfinance clients to the society. Welfare theory claim that depth is the weight of a clients in the social welfare function, therefore weight depends on the preference of the society (Schreiner, 2002).

The most popular proxy for depth of outreach is average loan size. Smaller average loan size proclaims that microfinance reaching out to the poorer clients, showing greater outreach depth. Alternatively, indirect proxies of depth of outreach could be: (i) location, with rural areas preferred to urban areas; (ii) sex, with outreach to women preferred; (iii) ethnicity, minorities are preferred; (iv) education, less education is preferred; (v) access to public services, whereby a lack of access is preferred; and (vi) housing; with small and vulnerable houses preferred. Conversely breath of outreach measured by the number of clients has been served by the microfinance institutions or the active number of borrowers. The future time frame or the duration of the supply of microfinance services refers to the length of outreach. And lastly, the number of microcredit products or services provided to the clients will represent the scope of outreach of microfinance institutions.

A difference has been made between the achievement of social promise and the poverty alleviation of microfinance institutions by the standards report of the Social Performance Task Force (SPTF, 2009). On the other hand Zeller et al. argued that social performance measurement and social impact measurement is not the same. Social performance measurement should concentrate to the reach out measurement of microfinance program, whereas social impact measurement is associated with the outreach to poverty, the development in welfare, and the enhancement of quality of life of poorer clients (Zeller, Lapenu, \& Greeley, 2003).

\section{CONCLUSIONS AND RECOMMENDATIONS}

From the review of empirical evidence on the effect of microfinance institutional financial sustainability on social development and women empowerment in Malaysia, the current study observed that the current literature in this field is scarce. Most studies were based only on the descriptive presentation of microcredit programs. There are very few studies assessed the performance of the AIM with respect to the Social contribution as well women empowerment in Malaysia and compared with international context. The summary of literature review revealed that it is the unique goal of MFIs for poverty reduction mission through ensuring of financial sustainability while contribution impact in the society. It has also revealed that it is the way the social mission of poverty alleviation through serving the poorest has been overshadowed by profit motive. However, profit orientation of the microfinance industry also emphasis on profit earning. Thus, some microfinance institutions rediscover their operating efficiency through earning profit while some chose to serve better-off clients with bigger loan to manage their various costs. The studies also concluded that trade-off between serving the prime mission of poverty relief through reach out to the social mission and women empowerment and seeking financial self-solvency through serving better-off clients.

However, this study found that social mission and women empowerment achieved through financial performance is the going concern issues as of MFIs performing better financial performance. This finding might put institutional investors in dilemma. However, if profit orientation of MFIs overshadows their social objective, then dual mission might occur, but it's yet to confirm through empirical studies. Furthermore, some studies claimed that commercialization 
of microfinance institutions forces the interest rate increment to earn adequate profit to adhere shareholder demand. Logically lower interest rate helps poor to manage their repayment. However, managing small loan in rural area is also a matter of high operating cost. Some studies therefore indicated that institutions often serve better-off poor clients with the bigger loan size to minimize their operational cost in some region. But if microfinance institutions choose to serve wealthier clients that would be considered as social mission and women empowerment.

Therefore, microfinance institutions in around countries confined in both goals, but yet to unanswered through empirical studies. Especially there are very limited studies found on about social mission and women empowerment achieved through financial performance in Malaysia. Thus, this study aims to identify the effects of the microfinance institution's (MFIs) financial sustainability on social development and women empowerment in Malaysia and comparisons between the microfinance institutions (MFIs) of the Bangladesh.

\section{ACKNOWLEDGEMENT}

The authors gratefully acknowledged the financial support for this research from the Fundamental Research Grant Scheme (FRGS) of Project No. FRGS/1/2018/SS01/UNISEL/02/2.

\section{REFERENCES}

Abeysekera, S., Oguzoglu, U., \& Le, T. T. (2014). Sustainability and Mission Drift: Do Microfinance Institutions in Vietnam Reach the Poor? Microfinance Institutions: Financial and Social Performance, 99.

Abrar, A., \& Javaid, A. Y. (2014). Commercialization and Mission Drift-A Cross Country Evidence on Transformation of Microfinance Industry. International Journal of Trade, Economics and Finance, 5(1), 122-125.

Acclassato, D. H. (2008). Do interest rate ceilings really protect poors and small enterprises? Les plafonnements de taux d'intérêt en microfinance servent-ils réellement les pauvres et petits opérateurs économiques?, 36(1), 93-109+113+116.

Aczel, A., \& Sound erpandian, J. (2006). Complete business statistics. New York: McGrawHill.

Agbodjan, J. P. (2002). Prudential regulation in decentralised financial system. La réglementation prudentielle dans les systèmes financiers décentralisés, 30(119), 63-71.

Ahlin, C., Lin, J., \& Maio, M. (2011). Where does microfinance flourish? Microfinance institution performance in macroeconomic context. Journal of Development Economics, 95(2), 105 120. doi: 10.1016/j.jdeveco.2010.04.004

Ahmed, M. (2006). Impact of Rural Development Scheme on Poverty Alleviation: A Case Study. Research, Planning and Development Division Islami Bank Bangladesh Limited. Dhaka, Bangladesh

Ahmed, S. M., Adams, A. M., Chowdhury, M., \& Bhuiya, A. (2000). Gender, socioeconomic development and health-seeking behaviour in Bangladesh. [doi: DOI: 10.1016/S02779536(99)00461-X]. Social Science \& Medicine, 51(3), 361-371.

AIM, P. (2013). http://www.aim.gov.my/ cms/englishversion/index_eng.html. [28 April 2013]. Akula, V. (2010). Clinton Global Initiative. New York, USA.

Al Atoom, R. O., \& Abu Zerr, A. E. (2012). Macro and microfinancial factors that assures Jordanian Microfinance Institutions' (MFIs) financial sustainability. European Journal of Economics, Finance and Administrative Sciences, (54), 146-160. 
Alam, M. N. (2009). Interest-Free Microfinance to Micro Entrepreneurs in Rural Bangladesh. Paper presented at the First International Microfinance Conference on Microfinance, ULB Brussels,June 2-4,.

Anduanbessa, T. (2009). Statistical analysis of the performance of microfinance institutions: The Ethiopian case. Savings and Development, 33(2), 183-198.

Annim, S. K. (2012). Targeting the Poor versus financial sustainability and external funding: Evidence of microfinance institutions in Ghana. Journal of Developmental Entrepreneurship, 17(03), 1250016.

Ansoff, H. I. (1965). Corporate strategy: business policy for growth and expansion: McGrawHill Book.

APEC. (2005). The Need and Availability of Micro Finance Service for the Micro Enterprise: Bringing multi-level Good Practices into Local Context. In S. a. M. E. w. g. APEC (Ed.).

Armendariz, B., D'Espallier, B., Hudon, M., \& Szafarz, A. (2011). Subsidy Uncertainty and Microfinance Mission Drift. CEB working paper 11, Université Libre de Bruxelles.

Armendariz, B., \& Morduch, J. (2005). The economics of microfinance, Boston: MIT Press.

Armendáriz, B., \& Morduch, J. (2010). The Economics of Microfinance (second ed.). Cambridge: MIT Press.

Armendáriz, B., \& Szafarz, A. (2009). On Mission Drift in Microfinance Institutions. CEB working paper 9, Université Libre de Bruxelles

Armendáriz, B., \& Szafarz, A. (2011a). On Mission Drift in Microfinance Institutions. The Handbook of Microfinance, 341-366.

Armendáriz, B., \& Szafarz, A. (2011b). On mission drift in microfinance institutions. The handbook of microfinance, 341, 366.

Armendariz de Aghion, B., \& Morduch, J. (2005). The economics of microfinance: Cambridge, MA: MIT Press.

Arrow, K. J. (1971). The theory of risk aversion. Essays in the theory of risk-bearing, 90-120.

Arvelo, M., Bell, J.-L., Novak, C., Rose, J., \& Venugopal, S. (2008). Morgan Stanley's

Approach to Assessing Credit Risks in the Microfinance Industry. Journal of Applied Corporate Finance, 20(1), 124-134.

Ayayi, A. G., \& Sene, M. (2010). What drives microfinance institution's financial sustainability. The Journal of Developing Areas, 44(1), 303-324.

Ayele, G. T. (2015). Microfinance Institutions in Ethiopia, Kenya and Uganda: Loan Outreach to the Poor and the Quest for Financial Viability. African Development Review, 27(2), 117 129.

B.B.S. (2008). Statistical Yearbook of Bangladesh, 2008. : Planning Division, Ministry of Planning, Government of the People's Republic of Bangladesh.

B.B.S. (2010). Statistical Yearbook of Bangladesh, 2010. : Planning Division, Ministry of Planning, Government of the People's Republic of Bangladesh.

Bajaj, V. (2010). Microlender, First in India to Go Public, Trades Higher, The New York Times.

Balc, L. B., Ilies, R., Cioban, B., \& Cuza, B. (2013). Corporate Governance: Conceptual Approaches. [Article]. Managerial Challenges of the Contemporary Society, (5), 14-17.

Basharat, B., Hudon, M., \& Nawaz, A. (2015). Does efficiency lead to lower prices? A new perspective from microfinance interest rates. Strategic Change, 24(1), 49-66. 
Basher, M. (2007). Empowerment of microcredit participants and its spillover effects: evidence from the Grameen Bank of Bangladesh. The Journal of Developing Areas, 40(2), 173183.

Basher, M. (2010). Promotional role of microcredit: Evidence from the Grameen Bank of Bangladesh. Journal of International Development, 22(4), 521-529.

Bassem, B. S. (2009). Governance and performance of microfinance institutions in Mediterranean countries. Journal of Business Economics and Management, 10(1), 31-43.

Bassem, B. S. (2012). Social and financial performance of microfinance institutions: Is there a trade-off? Journal of Economics and International Finance, 4(4), 92-100.

Beck, T., Demirgüç-Kunt, A., \& Levine, R. (2007). Finance, inequality and the poor. Journal of economic growth, 12(1), 27-49.

Berger, M., Goldmark, L., \& Sanabria, T. M. (2006). An inside view of Latin American microfinance: IDB.

Berle, A., \& Means, G. (1968). The modern corporation and private property, 1932. McMillan, New York, NY.

Bhagat, S., \& Bolton, B. (2008). Corporate governance and firm performance. Journal of Corporate Finance, 14(3), 257-273.

Bhanot, D., Bapat, V., \& Connelly, J. (2015). Sustainability index of micro finance institutions (MFIs) and contributory factors. International Journal of Social Economics, 42(4).

Blanco, A., Pino-Mejías, R., Lara, J., \& Rayo, S. (2013). Credit scoring models for the microfinance industry using neural networks: Evidence from Peru. Expert Systems with Applications, 40(1), 356-364.

Bou Kheir, R., Nekhili, M., Jokung, O., Chtioui, T., \& Bellalah, M. (2015). A conditional regression-tree analysis for predicting portfolio at risk in profit microfinance institutions. Available at SSRN.

Brau, J. C., Cardell, S. N., \& Woodworth, W. P. (2015). Does Microfinance Fill the Funding Gap for Microentrepreneurs? A Conceptual Analysis of Entrepreneurship Seeding in Impoverished Nations. International Business Research, 8(5), p30.

Briere, M., \& Szafarz, A. (2015). Does commercial microfinance belong to the financial sector? Lessons from the stock market. World Development, 67, 110-125.

Brière, M., \& Szafarz, A. (2013). Investment in microfinance equity: Risk, return, and diversification benefits. Return, and Diversification Benefits (January 5, 2013).

Burgis, T. (2008). Microfinance commercialisation warning, Financial Times.

Business, B. (2007). Online Extra: Yunus Blasts Compartamos. Bloomberg Business.

Campion, A., White, V., \& Network, M. (1999). Institutional metamorphosis: Transformation of microfinance NGOs into regulated financial institutions: MicroFinance Network.

Caserta, M., \& Reito, F. (2013). Outreach and mission drift in microfinance: An interpretation of the new trend. Economics Bulletin, 33(1), 167-178.

CGAP. (2003). Microfinance Consensus Guidelines. Washington: CGAP/The World Bank Group.

CGAP. (2004). Key Principles of Microfinance, from Retrieved from http://www.cgap.org/publications/keyprinciples-microfinance

CGAP. (2005). Mapping of funding flows, Washington, DC: CGAP.

Chahine, S., \& Tannir, L. (2010). On the social and financial effects of the transformation of microfinance NGOs. Voluntas: International Journal of Voluntary and Nonprofit Organizations, 21(3), 440-461. 
Chaves, R. A., \& Gonzalez-Vega, C. (1996). The design of successful rural financial intermediaries: Evidence from Indonesia. World Development, 24(1), 65-78.

Chen, G., Rasmussen, S., Reille, X., \& Rozas, D. (2010). Indian Microfinance Goes Public: The SKS Initial Public Offering. CGAP Focus Note, 65.

Chenuos, N. K., Mohamed, A., \& Bitok, S. K. (2014). Effects of Corporate Governance on Micro Finance Institutions Financial Sustainability in Kenya. European Journal of Business and Management, 6(30), 71-81.

Chijoriga, M. M. (2000). The performnace and sustainability of micro financing institutuions in Tanzania. Journal fur Entwicklungspolitik, 16(3), 275-301.

Chowdhury, A. (2001). "The Role of Micro-credit in Alleviation of Poverty: A study of the Grameen Bank in Bangladesh". Department of Finance and Banking, University of Dhaka, Bangladesh. Dhaka.

Chowdhury, M., Ghosh, D., \& Wright, R. (2005). The impact of micro-credit on poverty: evidence from Bangladesh. Progress in Development studies, 5(4), 298.

Christen, R. P., \& Cook, T. (2001). Commercialization and mission drift: The transformation of microfinance in Latin America: Consultative group to assist the poorest (CGAP).

Christen, R. P., \& Drake, D. (2002). Commercialization. The new reality of microfinance. The commercialization of microfinance: Balancing business and development, 2-20.

Christen, R. P., Drake, D., \& Rhyne, E. (2002). The commercialization of microfinance: Balancing business and development. Kumarian, West Hartford.

Christopher, J. (2010). Corporate governance-A multi-theoretical approach to recognizing the wider influencing forces impacting on organizations. Critical Perspectives on Accounting, 21(8), 683-695.

Conroy, J. D. (2002). Microfinance in Malaysia: Time to rebuild

Cox, J. W., \& Hassard, J. (2005). Triangulation in organizational research: a re-presentation. Organization, 12(1), 109-133.

Crabb, P. (2008). Economic freedom and the success of microfinance institutions. Journal of Developmental Entrepreneurship, 13(2), 205-219.

Creswell, J. W. (2013). Research design: Qualitative, quantitative, and mixed methods approaches: Sage publications.

Cull, R., Demirgu“ç-Kunt, A., \& Morduch, J. (2007). Financial performance and outreach: A global analysis of leading microbanks. The Economic Journal, 117(517), F107-F133.

Cull, R., Demirgüç-kunt, A., \& Morduch, J. (2007). Financial performance and outreach: A global analysis of leading microbanks. Economic Journal, 117(517), F107-F133.

Cull, R., Demirgüç-Kunt, A., \& Morduch, J. (2009). Microfinance Meets the Market. The Journal of Economic Perspectives, 23(1), 167-192. doi: 10.2307/27648299

Cull, R., Demirgüç-Kunt, A., \& Morduch, J. (2011). Does regulatory supervision curtail microfinance profitability and outreach? World development, 39(6), 949-965.

Cull, R., Demirgüç-Kunt, A., \& Morduch, J. (2014). Banks and microbanks. Journal of Financial Services Research, 46(1), 1-53.

Cull, R., \& Morduch, J. (2007). Financial performance and outreach: a global analysis of leading microbanks. The Economic Journal, 117(517), F107-F133.

Cull, R. J., Demirgüç-Kunt, A., \& Morduch, J. (2006). Financial performance and outreach: a global analysis of leading microbanks (Vol. 3827): World Bank Publications.

D'Espallier, B., Hudon, M., \& Szafarz, A. (2013). Unsubsidized microfinance institutions. Economics Letters, 120(2), 174-176. 
Daily, C. M., Dalton, D. R., \& Cannella, A. A. (2003). Corporate governance: Decades of dialogue and data. Academy of management Review, 28(3), 371-382.

Davis, J. H., Schoorman, F. D., \& Donaldson, L. (1997). Toward a stewardship theory of management. Academy of management Review, 22(1), 20-47.

De Crombrugghe, A., Tenikue, M., \& Sureda, J. (2008). Performance analysis for a sample of microfinance institutions in India. Annals of Public and Cooperative Economics, 79(2), 269-299.

Dey, S. K. (2015). Challenges \& Issues of Microfinance in India. Journal of Economics and Sustainable Development, 6(7), 195-198.

Dieckmann, R., Speyer, B., Ebling, M., \& Walter, N. (2007). Microfinance: An emerging investment opportunity. Deutsche Bank Research. Current Issues. Frankfurt. Ding, Z., Sun, S. L., \& Au, K. (2014). Angel investors' selection criteria: A comparative institutional perspective. Asia Pacific Journal of Management, 31(3), 705-731.

Donaldson, T., \& Preston, L. E. (1995). The stakeholder theory of the corporation: Concepts, evidence, and implications. Academy of management Review, 20(1), 65-91.

Dossey, L. (2007). The Peasant and the Professor: On Trust, Microcredit, and World Poverty.. EXPLORE: The Journal of Science and Healing, 3(5), 433-444.

Dowla, A. (2006). In credit we trust: Building social capital by Grameen Bank in Bangladesh. Journal of Socio-Economics, 35(1), 102-122.

Drake, D., \& Rhyne, E. (2002). Commercialization of Microfinance. Bloomfield, Conn.

Dunford, C. (2000). In Search of" Sound Practices" for Microfinance. Journal of Microfinance/ESR Review, 2(1), 6-12.

Economist, T. (2008). Poor people, rich returns: Is it acceptable to profit from the poor?, The Economist.

Economist, T. (2009). Froth at the bottom of the pyramid: Is microfinance going the same way as subprime mortgages?, The Economist.

Eisenhardt, K. M. (1989). Agency theory: An assessment and review. Academy of management Review, 14(1), 57-74.

Epstein, M. J., \& Yuthas, K. (2011). The critical role of trust in microfinance success: Identifying problems and solutions. Journal of Developmental Entrepreneurship, 16(4), 477-497.

Epstein, M. J., \& Yuthas, K. (2013). Rural microfinance and client retention: Evidence from Malawi. Journal of Developmental Entrepreneurship, 18(1).

Evans, J. (2010). Microfinance's Midlife Crisis, The Wall Street Journal.

Fama, E. F., \& Jensen, M. C. (1983). Agency problems and residual claims. Journal of law and Economics, 327-349.

Faridi, R. (2004). Essays on Microcredit Programs and Evaluation of Women's Success. (Doctor of Philosophy in Economics), State University, Blacksburg, Virginia.

Ferdousi, F. (2015). Impact of microfinance on sustainable entrepreneurship development. Development Studies Research, 2(1), 51-63.

Fernandez, A. (2010). Microcredit and Women's Outward Mobility in Rural Bangladesh: A Study of the Grameen Bank.

Fitch. (2009). Microfinance - Testing its resilience to the global financial crisis. New York: Fitch Ratings.

Frank, C., Lynch, E., \& Schneider-Moretto, L. (2008). Stemming the tide of mission drift: 
microfinance transformations and the double bottom line. Washington, DC: Women's World Banking.

Freeman, R. E. (2010). Strategic management: A stakeholder approach: Cambridge University Press.

Freeman, R. E., \& Evan, W. M. (1991). Corporate governance: A stakeholder interpretation. Journal of Behavioral Economics, 19(4), 337-359.

Freeman, R. E., Harrison, J. S., \& Wicks, A. C. (2007). Managing for stakeholders: Survival, reputation, and success: Yale University Press.

Friedman, A. L., \& Miles, S. (2006). Stakeholders: Theory and practice: Oxford University Press.

Galema, R., Lensink, R., \& Spierdijk, L. (2011). International diversification and Microfinance. Journal of International Money and Finance, 30(3), 507-515.

Gashayie, A. (2014). Relationship of financial Sustainability and Outreach in Ethiopian Microfinance Institutions: Empirical Evidence. Research Journal of Finance and Accounting, 5(17), 207-211.

Ghosh, S., \& Van Tassel, E. (2008). A model of mission drift in microfinance institutions. Department of Economics, Florida Atlantic University, December.

Gibbons, D. S., \& Meehan, J. W. (1999). The microcredit summit's challenge: Working toward institutional financial self-sufficiency while maintaining a commitment to serving the poorest families. Journal of Microfinance/ESR Review, 1(1), 131-192.

Gokhale, K. (2009a). As Microfinance Grows in India, So Do Its Rivals, The Wall Street Journal.

Gokhale, K. (2009b). A Global Surge in Tiny Loans Spurs Credit Bubble in a Slum, The Wall Street Journal.

Goodman, P. (2006). Microfinance investment funds: Objectives, players, potential Microfinance investment funds (pp. 11-45): Springer.

Grameen, B. (2010). Grameen Bank performances indicators and ratio analysis. Retrieved from http://www.grameeninfo.org/index.php?option=com_content\&task=view\&id=632\&Itemid=664 Greene, W. H. (2003). Econometric analysis. New York: Granite Hill Publishers.

Gregoire, J. R., \& Ramírez Tuya, O. (2006). Cost efficiency of microfinance institutions in Peru: A stochastic frontier approach. Latin American Business Review, 7(2), 41-70.

Gujarati, D. (2003). Basic Econometrics Fourth Edition McGraw Hill Gujarati, DN,(2003). Basic Econometrics: McGraw Hill. International Edition.

Guntz, S. (2011). Sustainability and profitability of microfinance institutions. CAIFD-Center for Applied International Finance and Development, Research paper, 4, 2011.

Gutiérrez-Nieto, B., Serrano-Cinca, C., \& Mar Molinero, C. (2007). Microfinance institutions and efficiency. Omega, 35(2), 131-142. http://dx.doi.org/10.1016/j.omega.2005.04.001

Gutiérrez-Nieto, B., Serrano-Cinca, C., \& Mar Molinero, C. (2009). Social efficiency in microfinance institutions. Journal of the Operational Research Society, 60(1), 104-119.

Habib, M. A., Haque, M. S., Mian, M. R. U., \& Bashar, M. A. (2004). Micro Credit: An Experience of Islami Bank Bangladesh Limited. Department of Agricultural Finance Bangladesh Agricultural University, Mymensingh-2202, Bangladesh.

Hartarska, V., \& Nadolnyak, D. (2007). Do regulated microfinance institutions achieve better sustainability and outreach? Cross-country evidence. Applied Economics, 39(10), 12071222.

Hermes, N., \& Lensink, R. (2011). Microfinance: its impact, outreach, and sustainability. World development, 39(6), 875-881. 
Hermes, N., Lensink, R., \& Meesters, A. (2011). Outreach and Efficiency of Microfinance Institutions. World Development, 39(6), 938-948.

Hishigsuren, G. (2006). Transformation of Micro-finance Operations from NGO to Regulated MFI. IDEAS, USA.

Hollis, A., \& Sweetman, A. (1998). Microcredit: What can we learn from the past? World Development, 26(10), 1875-1891.

Hossain, M. (1988). Credit for the Alleviation of Rural Poverty: The Grameen Bank in Bangladesh (IFPRI, Trans.). Washington DC.

Hossain, N. (2005). Productivity and Virtue: Elite Categories of the Poor in Bangladesh.World Development, 33(6), 965-977.

Hudon, M. (2006). Financial performance, management and ratings of the microfinance institutions: Do subsidies matter? : Working Paper, Solvay Business School, University of Brussels.

Hudon, M., \& Traca, D. (2011). On the Efficiency Effects of Subsidies in Microfinance: An Empirical Inquiry. World Development, 39(6), 966-973.

Hulme, D., \& Mosley, P. (1996). Finance against poverty (Vol. 2): Psychology Press.

Im, J., \& Sun, S. L. (2014). Profits and outreach to the poor: The institutional logics of microfinance institutions. Asia Pacific Journal of Management, 1-23.

Im, J., \& Sun, S. L. (2015). Profits and outreach to the poor: The institutional logics of microfinance institutions. [Article]. Asia Pacific Journal of Management, 32(1), 95-117.

Iskenderian, M. E. (2011). [Five Lessons for the Microfinance Industry].

Janda, K., \& Zetek, P. (2014). Survey of Microfinance Controversies and Challenges.

Jeje, K. (2014). Intensive Growth Strategies and Outreach Performance of Tanzania-Based Savings and Credit Cooperative Societies. International Journal of Business and Management, $10(1), \mathrm{p} 124$.

Jensen, M. C., \& Meckling, W. H. (1979). Theory of the firm: Managerial behavior, agency costs, and ownership structure: Springer.

Jolis, A. ( 1996, 14.09.2010). "The Good Banker" Bangladesh Brue of Statistics (BBS) BD Info The Daily Independent. Retrieved from http://www.bbs.gov.bd/index5.php?category=123

Kabir Hassan, M., \& Tufte, D. R. (2001). The X-Efficiency of a Group-Based Lending Institution: The Case of the Grameen Bank. World Development, 29(6), 1071-1082.

Kar, A. K. (2012). Mission drift in microfinance: are the concerns really worrying? Recent crosscountry results. International Review of Applied Economics, 27(1), 44-60.

Kar, A. K. (2013a). Double bottom lines in microfinance: are they mutually exclusive? Journal of Small Business \& Entrepreneurship, 26(1), 87-107.

Kar, A. K. (2013b). Mission drift in microfinance: are the concerns really worrying? Recent crosscountry results. International Review of Applied Economics, 27(1), 44-60.

Kar, A. K., \& Swain, R. B. (2014). Interest rates and financial performance of microfinance institutions: Recent global evidence. European Journal of Development Research, 26(1), 87-106.

Karim, L. (2008). The Grameen Bank, NGOs, and Neoliberalism in Bangladesh (Vol. 20(1), pp. 5-29). Los Angeles, London, New Delhi and Singapore: SAGE Publications.

Kereta, B. B. (2007). Outreach and financial performance analysis of microfinance institutions in Ethiopia. Paper presented at the African Economic Conference, Addis Ababa. 
Khandker, S. R. (1998). Fighting Poverty with Microcredit: Experience in Bangladesh. Oxford University Press, Inc. New York. .

Khandker, S. R., \& Chowdbury, O. H. (1996). Targeted Credit Programme and Rural Poverty in Bangladesh (pp. 15). Washington, D.C.: World Bank

Khandker, S. R., \& Khalily, B. (1996). The Bangladesh Rural Advancement Committee's Credit Programs. World Bank.

Kinde, B. A. (2012). Financial sustainability of microfinance institutions (MFIs) in Ethiopia. European Journal of Business and Management, 4(15), 1-10.

Kipesha, E. F., \& Zhang, X. (2013). Sustainability, Profitability and Outreach Tradeoffs: Evidences from Microfinance Institutions in East Africa. European Journal of Business and Management, 5(8), 136-148.

Kowalik, M. (2010). Creditworthiness of the Poor: A Model of the Grameen Bank: DIANE Publishing.

Krauss, N., \& Walter, I. (2009). Can microfinance reduce portfolio volatility? Economic Development and Cultural Change, 58(1), 85-110.

Kuhinur, S., \& Rokonuzzaman, M. (2010). Impact of Grameen Bank micro credit on change in livelihood status of women beneficiaries. Journal of the Bangladesh Agricultural University, 7(2), 381.

Kyereboah-Coleman, A., \& Osei, K. A. (2008). Outreach and profitability of microfinance institutions: the role of governance. Journal of Economic Studies, 35(3), 236-248.

Lebovics, M., Hermes, N., \& Hudon, M. (2015). ARE FINANCIAL AND SOCIAL EFFICIENCY MUTUALLY EXCLUSIVE? A CASE STUDY OF VIETNAMESE MICROFINANCE INSTITUTIONS. Annals of Public and Cooperative Economics, n/an/a. doi: 10.1111/apce.12085

Ledgerwood, J. (1998). Microfinance handbook: An institutional and financial perspective: World Bank Publications.

Ledgerwood, J. (1999). Sustainable Banking with the Poor Microfinance Handbook: An Institutional and Financial Perspective. Washington, DC.: The World Bank.

Ledgerwood, J., Earne, J., \& Nelson, C. (2013). The new microfinance handbook: A financial market system perspective: World Bank Publications.

Ledgerwood, J., \& White, V. (2006). Transforming microfinance institutions: providing full financial services to the poor: World Bank Publications.

Lee, S. (2009). Corporate Governance and Firm Performance (Doctor of Philosophy (PhD) Research), The University of Utah. (UMI Number: 3364922)

Lenssen, G., Nijhof, A., Roger, L., Kievit, H., Bakker, A., \& Schaveling, J. (2014). Governance and microfinance institutions. Corporate Governance, 14(5), 637-652.

Louis, P., Seret, A., \& Baesens, B. (2013). Financial efficiency and social impact of microfinance institutions using self-organizing maps. World Development, 46, 197-210.

M. Mizanur Rahmana, Jafrullahb, M., \& Islamc, A. T. (2008). Rural Development Scheme Bangladesh Limited (IBBL): Assessment Challenges. IIUM Journal of Economics and Management 16(2),139-163.

M.Salma. (2004). A Comparative Case Study on Outreach and Impact of Ikhtiar Loan Scheme and Special Program for Hardcore Poor in Seberang Perai Pulau Pinang. . (M.Phil ), University Science Malaysia. 
Maes, J. P., \& Reed, L. R. (2012). State of the microcredit summit campaign report 2012. Microcredit Summit Campaign.

Mahajan, V., \& Ramola, B. G. (1996). Financial services for the rural poor and women in India: Access and sustainability. Journal of International Development, 8(2), 211-224.

Mair, J., \& Marti, I. (2009). Entrepreneurship in and around institutional voids: A case study from Bangladesh. Journal of Business Venturing, 24(5), 419-435.

Malaysia. (2006). The 9th Malaysia plan: 2006-2010. Unit Economic Planing, Putra Jaya, Malaysia: Prime Minister's Department.

Malkin, E. (2008). Microfinance's Success Sets off a Debate in Mexico, The New York Times. Mallin, C. A. (2004). Corporate Governance: Oxford University Press.

Marr, A., \& Awaworyi, S. (2012). Microfinance social performance: A global empirical study. Applied Econometrics and International Development, 12(2), 51-68.

Mazumder, M. S. U., \& Lu, W. (2015). What Impact Does Microfinance Have on Rural Livelihood? A Comparison of Governmental and Non-Governmental Microfinance Programs in Bangladesh. World Development, 68(0), 336-354. http://dx.doi.org/10.1016/j.worlddev.2014.12.002

Mersland, R., \& Øystein Strøm, R. (2009). Performance and governance in microfinance institutions. Journal of Banking \& Finance, 33(4), 662-669.

Mersland, R., \& Strøm, R. Ø. (2008). Performance and trade-offs in microfinance organizationsdoes ownership matter? Journal of International Development, 20, 598-612.

Mersland, R., \& Strøm, R. Ø. (2010). Microfinance Mission Drift? World Development, 38(1), 28-36. doi: 10.1016/j.worlddev.2009.05.006

Mersland, R., \& Strøm, R. Ø. (2014). Measuring Microfinance Performance. Microfinance Institutions: Financial and Social Performance, 12.

Mersland, R., \& Urgeghe, L. (2013a). International Debt Financing and Performance of Microfinance Institutions. Strategic Change, 22(1-2), 17-29.

Mersland, R., \& Urgeghe, L. (2013b). Performance and international investments in microfinance institutions.

Meyer, J. (2015a). Social versus Financial Return in Microfinance. Working paper, Center for Microfinance, Zurich, Switzerland.

Meyer, J. (2015b). Social versus Financial Return in Microfinance. Available at SSRN 2580343.

Mia, M. A. (2014). Does lending to women affect revenue generation of microfinance institutions. Empir. Econom. Quant. Econ. Lett, 3(4), 59-65.

Millson, H. F. (2013). The Trade-Off Between Sustainability And Outreach: The Experience Of Commercial Microfinance Institutions.

MIX. (2005). The MicroBanking Bulletin No. 10.

MIX. (2008). The MicroBanking Bulletin No. 17.

MIX. (2009). About Microfinance: Who are the Microfinance Clients?

Morduch, J. (1998). Does microfinance really help the poor?: New evidence from flagship programs in Bangladesh: Research Program in Development Studies, Woodrow School of Public and International Affairs.

Morduch, J. (1999a). The microfinance promise. Journal of economic literature, 1569-1614.

Morduch, J. (1999b). The role of subsidies in microfinance: evidence from the Grameen Bank.

Journal of Development Economics, 60(1), 229-248.

http://dx.doi.org/10.1016/S0304-3878(99)00042-5 
Morduch, J. (2000). The Microfinance Schism. World Development, 28(4), 617-629. http://dx.doi.org/10.1016/S0305-750X(99)00151-5

Mori, N., Golesorkhi, S., Randøy, T., \& Hermes, N. (2015). Board Composition and Outreach Performance of Microfinance Institutions: Evidence from East Africa. Strategic Change, 24(1), 99-113.

Muwamba, D. (2012). Sustainability of MFIs through Governance Mechanisms: A crossCountry Analysis of Regulation on Outreach and Operational Self Sufficiency.

Nanayakkara, G. (2012). Measuring the performance of microfinancing institutions: a new approach. South Asia Economic Journal, 13(1), 85-104.

Navajas, S., Schreiner, M., Meyer, R. L., Gonzalez-Vega, C., \& Rodriguez-Meza, J. (2000). Microcredit and the Poorest of the Poor: Theory and Evidence from Bolivia. World Development, 28(2), 333-346.

Nestor, C. (2011). Commercialization of Microfinance.

Nurmakhanova, M., Kretzschmar, G., \& Fedhila, H. (2015). Trade-off between financial sustainability and outreach of microfinance institutions. Eurasian Economic Review, 120.

Okumu, L. J. (2007). The microfinance industry in Uganda: sustainability, outreach and regulation. Stellenbosch: University of Stellenbosch.

Olasupo, M. A., Afolami, C. A., \& Shittu, A. M. (2014). Outreach and Financial Sustainability of Microfinance Banks in Southwest Nigeria. International Journal of Economics and Finance, 6(2), p25.

Olivares-Polanco, F. (2005). Commercializing microfinance and deepening outreach? Empirical evidence from Latin America. Journal of Microfinance/ESR Review, 7(2), 47-69.

Osmani, L. N. K. (1998). Impact of Credit on the Relative Well-Being of Women Evidence from the Grameen Bank. Institute of Development Studies, 29 (04).

Parveen, J. A. (2009). Sustainability Issues Of Interest-Free Micro-Finance Institutions In Rural Development And Poverty Alleviation. The Bangladesh Perspective. Theoretical and Empirical Researches in Urban Management, 2(11).

Peng, M. W., Sun, S. L., Pinkham, B., \& Chen, H. (2009). The Institution-Based View as a Third Leg for a Strategy Tripod. The Academy of Management Perspectives, 23(3), 6381.

Penrose, E. T. (1995). The Theory of the Growth of the Firm: Oxford university press.

Piot-Lepetit, I., \& Nzongang, J. (2014). Financial sustainability and poverty outreach within a network of village banks in Cameroon: A multi-DEA approach. European Journal of Operational Research, 234(1), 319-330.

Pitt, M. M., \& Khandker, S. R. (1998). Imapct of Group Based Credit Programs on Poor Households in Bangladesh: Does the Gender of perticipants Matter ?. The Journal of Polotical Economy, 106(05), 958-996.

Porter, M. E. (1980). Competitive strategy: Techniques for analyzing industries and competition. New York, 300.

Porter, M. E. (1985). Competitive advantage: creating and sustaining superior performance. New York.

Porter, M. E. (2008). Competitive strategy: Techniques for analyzing industries and competitors: Simon and Schuster.

Post, J. E., Preston, L. E., \& Sachs, S. (2002). Redefining the corporation: Stakeholder management and organizational wealth: Stanford University Press. 
Poyo, J., \& Young, R. (1999). Commercialization of microfinance: A framework for Latin America. USAID. Washington DC, USA.

Prahalad, C. K., \& Hamel, G. (2006). The core competence of the corporation: Springer.

Quayes, S. (2012). Depth of outreach and financial sustainability of microfinance institutions. Applied Economics, 44(26), 3421-3433.

Quayes, S. (2015). Outreach and performance of microfinance institutions: a panel analysis. Applied Economics, 47(18), 1909-1925.

Quayes, S., \& Hasan, T. (2014). Financial disclosure and performance of microfinance institutions. Journal of Accounting \& Organizational Change, 10(3), 314-337.

Radhakrishnan, S. (2015). "Low Profile" or Entrepreneurial? Gender, Class, and Cultural Adaptation in the Global Microfinance Industry. World Development, 74, 264-274.

Rahman, M., \& Ahmad, F. (2010). Impact of microfinance of IBBL on the rural poor's livelihood in Bangladesh: an empirical study. International Journal of Islamic and Middle Eastern Finance and Management, 3(2), 168-190.

Rahman, M. A., \& Mazlan, A. R. (2014). Determinants of Financial Sustainability of Microfinance Institutions in Bangladesh. International Journal of Economics and Finance, 6(9), p107.

Rahman, M. W., \& Luo, J. (2012). Sustainability of NGO-type microfinance service provider in Shaanxi, China: Peer with Grameen Bank, Bangladesh. African Journal of Business Management, 6(15), 5319-5327.

Rao, K. R. M. (2014). Concepts And Measures of Outreach and Sustainability in Microfinance Institutions: A comprehensive literature review. Research Journal of Finance and Accounting, 5(21), 41-48.

Rauf, S. A., \& Mahmood, T. (2009). Growth and performance of microfinance in Pakistan. Pakistan Economic and Social Review, 99-122.

Renneboog, L., Ter Horst, J., \& Zhang, C. (2008). Socially responsible investments: Institutional aspects, performance, and investor behavior. Journal of Banking \& Finance, 32(9), 1723 1742.

Rhyne, E. (1998). The Yin and Yan of micro-finance: Reaching the poor and sustainability. Micro Banking Bulletin, 2(1), 608.

Rhyne, E. (2001). Mainstreaming microfinance: How lending to the poor began, grew, and came of age in Bolivia: Kumarian Press Bloomfield, CT.

Rhyne, E. (2008). Transforming Microfinance Institutions: Providing Full Financial Services to the Poor. International Journal of Social Economics, 35(11), 879-882.

Rhyne, E., \& Otero, M. (2006). Microfinance through the next decade: Visioning the who, what, where, when and how: ACCION International.

Robinson, M. (2001). The microfinance revolution: Sustainable banking for the poor. Washington, DC: The World Bank.

Rosenberg, R. (2007). CGAP Reflections on the Compartamos Initial Public Offering. CGAP Focus Note, 42.

S\&P. (2007). Microfinance: Taking Root In The Global Capital Markets. New York: Standard \& Poor's.

Sachs, S., Groth, H., \& Schmitt, R. (2010). The 'stakeholder view'approach: An untapped opportunity to manage corporate performance and wealth. Strategic Change, 19(3-4), 147162. 
Sachs, S., \& Rühli, E. (2011). Stakeholders matter: A new paradigm for strategy in society: Cambridge University Press.

Salmon, F. (2011). Why Yunus is right about for-profit microfinance, Reuters.

Saltmarsh, M., \& Contiguglia, C. (2009). Some Fear Profit Motive to Trump Poverty Efforts in Microfinance, The New York Times.

Schreiner, M. (2002). Aspects of Outreach: A Framework for the Disscussion of the Social Benefits of Microfinance. Microfinance Risk Management. and Center for Social Development, Washington University in St. Louis Campus, St. Louis, USA (Online). Retrieved from http://www. microfinancegateway. org.

Schreiner, M. (2003). A Cost Effectiveness Analysis of the Grameen Bank of Bangladesh. Development Policy Review, 21, 357-382.

Seibel, H. D., \& Torres, D. (1999). Are Grameen Replications Sustainable, and Do They Reach the Poor? The Case of CARD Rural Bank in the Philippines. Journal of Microfinance, $1(1)$.

Sekabira, H. (2013). Capital Structure and Its Role on Performance of Microfinance Institutions: The Ugandan Case. Sustainable Agriculture Research, 2(3), p86.

Sengupta, R., \& Aubuchon, C. P. (2008). The Microfinance Revolution: An Overview. Federal Reserve Bank of St. Louis Review, 90(1).

Sengupta, R., \& Aubuchon, C. P. (2008). The microfinance revolution: An overview. Federal Reserve Bank of St. Louis Review, 90(January/February 2008).

Sim, J., \& Prabhu, V. V. (2013). Game theoretical approach to supply chain microfinance Advances in Production Management Systems. Sustainable Production and Service Supply Chains (pp. 48-53): Springer.

Siriaram, M., \& Upadhyayula, R. S. (2004). The Transformation of the Microfinance Sector in India: Experiences, Options, and Future. Journal of Microfinance/ESR Review, 6(2), 6.

SPTF. (2009). Social Performance Standards Report.

Sriram, M., \& Upadhyayula, R. (2002). The transformation of microfinance in India: Experiences, options and future: Indian Institute of Management Ahmedabad, Research and Publication Department.

Sriram, M. S. (2010). Commercialization of Microfinance in India: A Discussion on the Emperor's Apparel.

Steger, I. (2012). Microfinance Growing in Attraction to Private-Equity.

Strøm, R. Ø., D’Espallier, B., \& Mersland, R. (2014). Female leadership, performance, and governance in microfinance institutions. Journal of Banking \& Finance, 42(0), 60-75. http://dx.doi.org/10.1016/j.jbankfin.2014.01.014

Sveiby, K. E. (1997). The new organizational wealth: Managing \& measuring knowledge-based assets: Berrett-Koehler Publishers.

Syedah, A., Shan, E., Anum, B. S., Zeshan, A., \& Kaleem, K. M. (2013). Budding issues in Microfinance sector of Pakistan. Science International, 25(4).

Tchakoute-Tchuigoua, H. (2010). Is there a difference in performance by the legal status of microfinance institutions? Quarterly Review of Economics and Finance, 50(4), 436-442.

Tehulu, T. A. (2013). Determinants of Financial Sustainability of Microfinance Institutions in East Africa. European Journal of Business and Management, 5(17), 152-158. 
Thapa, G. (2007). Sustainability and governance of microfinance institutions: recent experiences and some lessons for Southeast Asia. Asian Journal of Agriculture and Development, 4(1), 17-37.

Tiwari, R., \& Anjum, B. (2015). Transformation from Microfinance to Bank: A Case Study of Bandhan. Arth prabandh: A Journal of Economics and Management, 4(3), 196-202.

Tucker, M. (2001). Financial performance of selected microfinance institutions: Benchmarking progress to sustainability. Journal of Microfinance/ESR Review, 3(2), 107-123.

Tucker, M., \& Miles, G. (2004). Financial performance of microfinance institutions: A comparison to performance of regional commercial banks by geographic regions. Journal of Microfinance/ESR Review, 6(1), 41-54.

Uddin, M. M. (2008). Credit for the Poor: The Experience of Rural Development Scheme of Islami Bank Bangladesh Ltd. The Journal of Nepalese Business Studies, 1(1).

Ugur, Z. (2006). Commercial Banks and Microfinance. CUREJ-College Undergraduate Research Electronic Journal, 35.

UNCDF. (2005). Blue Book, Geneva: UNCF Press.

Wernerfelt, B. (1984). A resource-based view of the firm. Strategic Management Journal, 5(2), 171-180.

Wijesiri, M., \& Meoli, M. (2015). Productivity change of microfinance institutions in Kenya: A bootstrap Malmquist approach. Journal of Retailing and Consumer Services, 25, 115121.

Wilburn, K., \& Wilburn, R. (2014). The double bottom line: Profit and social benefit. Business Horizons, 57(1), 11-20. http://dx.doi.org/10.1016/j.bushor.2013.10.001

Wilkins, \& Jennifer. (2007). Grameen: Banking for the Poor. From Grameen Bank Bhavan, Mirpur-1, Dhaka-1216, Bangladesh. Web site, available at: http://www.grameeninfo.org. Accessed August 25, 2007. Journal of Nutrition Education and Behavior, 39(6), 359-359.

Woller, G. (2002). The promise and peril of microfinance commercialization. Small Enterprise Development, 13(4), 12-21.

Woller, G., \& Schreiner, M. (2002). Poverty lending, financial self-sufficiency, and the six aspects of outreach. Disc. Paper, Ohio.

Woller, G. M., Dunford, C., \& Woodworth, W. (1999). Where to microfinance. International Journal of Economic Development, 1(1), 29-64.

Yaron, J. (1992). Successful rural finance institutions: World Bank.

Yaron, J. (1994). What makes rural finance institutions successful? The World Bank Research Observer, 9(1), 49-70.

Yaron, J., \& Manos, R. (2007). Determining the Self-Sufficiency of Microfinance Institutions. Savings and Development, 131-160.

Yunus, \& Abed. (2004). Poverty Matters, State of Microcredit Summit Campaign Report, Microcredit Summit.

Yunus, M. (1999). The Grameen Bank: Scientific American Inc.

Yunus, M. (2007). Creating a world without poverty: Social business and the future of capitalism: PublicAffairs.

Yunus, M. (2010) Clinton Global Initiative. New York, USA.

Zaman, H. (2000). Assessing the Poverty and Vulnerability Impact of Microcreedit in Bangladesh: A case study of BRAC: The World Bank. 
Zaman, H., President, W. B. O. o. t. S. V., \& Chief Economist, D. E. (1999). Assessing the poverty and vulnerability impact of micro-credit in Bangladesh: A case study of BRAC: World Bank, Development Economics, Office of the Senior Vice President and Chief Economist.

Zeller, M., \& Johannsen, J. (2006). Is there a difference in poverty outreach by type of microfinance institution? The case of Peru and Bangladesh. Paper presented at the Global Conference on Access to Finance: Building Inclusive Financial Systems. The World Bank and Brookings Institutions, Washington DC. Retrieved from http://info.worldbank. org/etools/docs/library/232695/ZellerJohannsen_Revisedpaper.pdf.

Zeller, M., Lapenu, C., \& Greeley, M. (2003). Measuring social performance of microfinance institutions: A proposal. Social Performance Indicators Initiative (SPI)-Final Report, Argidius Foundation and Consultative Group to Assist the Poorest (CGAP).

Zeller, M., \& Meyer, R. L. (2002). The triangle of microfinance: Financial sustainability, outreach, and impact: Intl Food Policy Res Inst.

\section{Copyrights}

Copyright for this article is retained by the author(s), with first publication rights granted to the journal. This is an open-access article distributed under the terms and conditions of the Creative Commons Attribution license (http://creativecommons.org/licenses/by/4.0) 